\title{
9. The media and international humanitarian law: Legal protections for journalists
}

\section{ABSTRACT}

Journalists and other media personnel perform a crucial role in armed conflicts. In the absence of functioning civil society, which, in peacetime can survey the behaviour of governments and other parties, and report on breaches of law, journalists are often the only parties on the ground able to document and publicise such breaches. Like humanitarian workers, they are often the only group that can bring to the attention of the world breaches of international humanitarian law and the horrific consequences which flow from armed conflict without limits. This article will consider the protections afforded to journalists under international humanitarian law and the practical assistance given to journalists by the International Committee of the Red Cross (ICRC).

\section{SOPHIA KAGAN and HELEN DURHAM}

\section{International lawyers, Melbourne}

DHE YEAR 2009 brought a renewed interest in the protection of war reporters among the Australian public following the release of the

1 film Balibo, a dramatised version of the killing of five journalists in East Timor in 1975. However, 2009, perhaps less conspicuously, also saw 130 other journalists around the world, perish while reporting news (INSI, 2009). A large portion of these victims were killed reporting on armed conflicts, from Somalia to Iraq to Afghanistan to the Philippines. Some were killed in crossfire, some by roadside bombs, and others were deliberately targeted and murdered with stunning contempt and indifference to the law that is in place to protect journalists from such violence.

Journalists and other media personnel perform a crucial role in armed conflicts. In the absence of functioning civil society, which, in peacetime can survey the behaviour of governments and other parties, and report on 
breaches of law, journalists are often the only parties on the ground able to document and publicise such breaches. Like humanitarian workers, they are often the only group that can bring to the attention of the world breaches of international humanitarian law and the horrific consequences which flow from armed conflict without limits.

In many instances the information that journalists gather can be critical in turning regional or global attention on a conflict, and even in triggering criminal investigations. Tragically, it is for this very reason that journalists are often most vulnerable to attack and murder by parties to the conflict who are trying to conceal their own atrocities.

This article will consider the protections afforded to journalists under international humanitarian law and the practical assistance given to journalists by the International Committee of the Red Cross (ICRC).

\section{A brief overview of international humanitarian law}

International humanitarian law is a set of rules that aim to limit the brutality of war, and in particular, to protect persons who are not participating in conflict (such as civilians, medical personnel, and aid workers), or who are no longer participating in conflict (such as injured or sick soldiers and prisoners of war).

These rules are enshrined in the Geneva Conventions of 1949 - a series of four international treaties which contain fundamental protections for civilians and wounded soldiers, and define the rules for treatment of prisoners of war. Two additional protocols (Additional Protocol I, Additional Protocol II) were enacted in 1977 to build on the text of the Geneva Conventions and adapt the Conventions to the changing nature of modern conflict. Importantly, Additional Protocol II finally expanded on the very limited provisions made in the Geneva Conventions with regard to non-international (or civil) armed conflicts. This is discussed further in section 4 of this article. Along with the red cross and red crescent, recently a third Additional Protocol was created to provide a third emblem of protection, the red crystal (ICRC, 2007).

While the Geneva Conventions are universally ratified, not all countries have agreed to the provisions found in the Additional Protocols (ICRC, 2008). This does not, however, mean that the important provisions of the Additional Protocols do not apply. International legal commentators agree that certain aspects of the Protocols have crystallised into customary international law-a 
non-treaty, but binding, law that is created through 'state practice' consistent with the 'law' and evidence that this state practice is motivated by a sense of legal obligation (opinio juris) (SS Lotus, 1927).

All States parties to the Geneva Conventions have an obligation to punish perpetrators of serious breaches of international humanitarian law. Each of the Conventions contains an obligation to:

search for persons alleged to have committed, or to have ordered to be committed ... grave breaches [of the Convention] and shall bring such persons, regardless of their nationality, before its own courts... or hand such persons over for trial to another [State Party to the Convention] ... ${ }^{1}$

Grave breaches include wilful killing, torture or inhuman treatment, such as biological experiments, wilfully causing great suffering or serious injury to body or health of persons protected by the Convention, and extensive destruction and appropriation of property, not justified by military necessity and carried out unlawfully and wantonly.

Consequently, States parties to the Conventions must either prosecute those who commit these grave breaches or extradite such individuals to a State that will prosecute them. There is no need to establish a nexus between the State exercising jurisdiction and the perpetrator, mere evidence that the crime was committed is sufficient. Failure to prosecute may, in certain circumstances, give rise to the prosecutor of the International Criminal Court being able to initiate prosecution.

Under the Geneva Conventions and Additional Protocol I and II , the ICRC is given a special mandate in international humanitarian law which, for example, includes the right to visit prisoners of war and civilian internees and offer its humanitarian services to parties involved in armed conflict. National Red Cross and Red Crescent Societies (such as Australian Red Cross or New Zealand Red Cross) also have specific roles to play during times of armed conflict. In addition, the ICRC as guardians of international humanitarian law, assist in the interpretation and the development of this area of international law.

\section{Protection afforded to journalists under international humanitarian law}

There are a number of different types of journalists who cover armed conflict. Journalists may, for example, be attached to or 'embedded in' the armed forces of one of the parties to the conflict. Or, they may be independent 
journalists who go into a conflict without the protection (but also without the restraint and possible censorship) of the military. Journalists may also be freelance, doing short term projects for a number of media employers. Although the distinction between the different types of journalists is significant in relation to capture or detainment, international humanitarian law largely treats all types of journalists in the same way.

\section{General principles regarding protection of journalists}

Journalists are one of the few categories of civilians which are specifically mentioned in international humanitarian law. As persons not taking an active part in the conflict, journalists benefit from the same protections afforded to civilians.

This principle is confirmed by Article 79 of Additional Protocol I to the Geneva Conventions, which states that:

Journalists engaged in dangerous professional missions in areas of armed conflict shall be considered as civilians ... [and] shall be protected as such under the Conventions and this Protocol, provided that they take no action adversely affecting their status as civilians...

Commentary by the ICRC on this article reveals that it is intended to have broad application. ${ }^{2}$ Though the Additional Protocol refers only to journalists, the Commentary states that this group includes any correspondent, reporter, photographer, and their technical film, radio and television assistants. The phrase 'professional mission' is also suitably broad and includes all activities which normally form part of the journalism profession in a general sense such as doing interviews, taking notes, taking photographs or films.

Finally, the description of professional missions as 'dangerous' is, again, not intended to narrow the breadth of the protection but rather to acknowledge that any professional activity exercised in an area affected by hostilities is dangerous by its very nature and is thus covered by the rule.

The suite of rights that journalists are entitled to as civilians includes protection from murder, torture (including cruel or inhuman treatment), corporal punishment, outrages upon personal dignity (in particular humiliating and degrading treatment), collective punishment and hostage taking.

Article 52 of Additional Protocol I requires parties to an armed conflict to take all reasonable precautions to ensure that attacks are only directed at 
military objectives. This means that they must not directly attack journalists or their equipment. In addition, media facilities (such as broadcasting centres) fall into the category of civilian objects and shall therefore not be the object of attack or reprisals.

Breach of these provisions (such as a deliberate attack causing the death or injury of a journalist not otherwise excusable in international humanitarian law) may constitute a grave breach of the Geneva Conventions - and hence a 'war crime' as previously discussed.

\section{Protection of journalists upon capture or detainment}

Although all types of journalists are protected by Article 79 of Additional Protocol I, embedded journalists (referred to as 'war correspondents' in international humanitarian law) have a unique entitlement to be treated as prisoners of war in case of capture during this conflict - a status which does not apply to other types of journalists.

Article 4(A)(4) of the Third Geneva Convention (relative to the treatment of prisoners of war), states that:

Persons who accompany the armed forces without actually being members thereof, such as ... war correspondents ... [are entitled to be treated as prisoners of war upon capture by the belligerent party] provided that they have received authorization, from the armed forces which they accompany, who shall provide them for that purpose with an identity card ...

Although entitled to prisoner of war status, war correspondents are not combatants (unlike soldiers) and maintain their status as civilians during conflict. The prisoner of war status is most likely provided for because of war correspondents' close association with the armed forces to which they are attached (Saul, 2008, p. 19). Within the context of an armed conflict there are benefits for a war correspondent to be deemed to have prisoner of war status as the potential to be classified as a spy due to potentially sensitive information obtained in a reporting role can have inherent dangers. As a prisoner of war an individual is provided with a range of protections which may not be available to a civilian engaged or working closely with the military.

The authorisation referred to in Article 4(A)(4) that war correspondents require from the armed forces is generally in the form of an identity card and

100 PACIFIC JOURNALISM REVIEW 16 (1) 2010 
can be demanded by enemy forces in order to decide on a war correspondent's prisoner of war status.

Though there have been embedded journalists in many conflicts, the numbers have substantially increased since the Gulf War in 1991. In the Iraq conflict, there were approximately 700 embedded journalists, including 500 from the US (Balguy-Gallois, 2004, p. 40).

Journalists that would not be classified as war correspondents - such as freelance journalists who work independently of any armed forces - cannot claim prisoner of war status in conflicts and are to be treated in the same way as any other non-combatants under international humanitarian law. As such under the Fourth Geneva Convention, if they find themselves 'in the hands of' a Party to the conflict of which they are not nationals, they are treated as 'protected persons'.

Being protected persons means that such journalists can be interned and detained but international humanitarian law only allows this if the security of the Detaining Power makes it absolutely necessary. In addition, a journalist who is interned can (under article 43 of the Fourth Convention) request a review of the internment 'as soon as possible' by an appropriate court or administrative board, and if internment is nonetheless decided on, this decision must be reviewed at least twice a year.

If a journalist is 'definitely suspected of or engaged in activities hostile to the security of the State', then that person loses whatever rights that are prejudicial to that State's security under article 5 of the Fourth Convention. Likewise, if this occurs in an occupied territory, a person may be detained if 'military security so requires'. However in each case, journalists, as protected persons, must nonetheless be treated with humanity and in accordance with a number of fundamental guarantees (such as an absolute prohibition of personal violence, torture and the like).

Finally, it is worth noting that journalists may also be arrested and detained under the local (domestic) criminal laws of the state in which they are operating - laws which may differ from the provisions of international humanitarian law.

Whether war correspondents with prisoner of war status, or ordinary journalists treated as civilians, if they are captured, arrested, interned or detained, journalists may be visited by representatives of the ICRC, who are able to check on their conditions of detainment. 


\section{Limits to the protection under international humanitarian law}

Despite the prohibition in international humanitarian law on attacks on journalists, safety in a war zone can never be assured even if international humanitarian law is respected.

Although Additional Protocol I requires armed forces to do everything feasible to distinguish between civilians and combatants (and civilian objects as opposed to military targets) and never use indiscriminate force, journalists may, on occasion, be mistaken for combatants or fall victim to stray bullets. This is especially a risk for embedded journalists who travel with armed forces, and may not adopt insignia distinguishing them as journalists.

Even when clearly identifiable as journalists, they are not immune from attack if they happen to be near a legitimate military target - in certain circumstances civilian casualties arising from attacks on military objectives do not violate international humanitarian law provided that they are not excessive or disproportionate to the military advantage anticipated from the attack.

\section{Loss of the protection under international humanitarian law}

\section{Loss of civilian status for journalists}

International humanitarian law, under article 79(2) of Additional Protocol I, grants journalists protection as civilians 'provided that they take no action adversely affecting their status as civilians.' This means that as civilians, journalists will, under Article 51(3) of Additional Protocol I enjoy protection unless (and for such time as) they take a 'direct part in hostilities'. Journalists are permitted their usual, accepted activities, but once they over-step the boundaries by directly engaging in hostilities, they may be captured by authorities, detained and even legitimately be subject to attack. In addition, as journalists are not members of the armed forces, they may be charged with perfidy under Article 37(1)(c) of Additional Protocol I.

The term 'direct participation in hostilities' lacks a clear definition. According to the ICRC Commentary on the draft of Article 51(3), "hostile acts (or direct participation in hostilities) means acts of war that by their nature or purpose strike at the personnel and matériel of enemy armed forces'. This means that the acts are likely to cause actual harm to the personnel and equipment of the enemy armed forces (ICRC, 2009).

It is clear that a journalist would be taking a direct part in hostilities if he or she, for example, took up arms, attempted to capture, injure or kill enemy forces, or purposefully damaged or destroyed enemy property for a military

102 PACIFIC JOURNALISM REVIEW 16 (1) 2010 
purpose. Less clear cut would be the acts of serving as guards, lookouts, intelligence agents or spies.

The ICRC's 'Interpretive Guidance on the Notion of Direct Participation in Hostilities' suggests that for direct participation in hostilities to be established, three criteria must be satisfied:

- the act must be likely to adversely affect the military operations or military capacity of a party to an armed conflict or, alternatively, to inflict death, injury, or destruction on persons or objects protected against direct attack (eg. civilians);

- there must be a direct causal link between the act and the harm likely to result from that act; and

- the act must be specifically designed to directly cause the required threshold of harm in support of a party to the conflict.

Activities that either directly or indirectly make 'a contribution to the war effort' such as participation in the transportation of weapons, weapons production, and combat logistical support are generally seen to be excluded from the definition of 'direct participation in hostilities', however there is some debate on this issue. The ICRC's Guidance notes that 'individual conduct that merely builds up or maintains the capacity of a party to harm its adversary, or which otherwise only indirectly causes harm, is excluded from the concept of direct participation in hostilities'.

Pertinently for journalists, dissemination of propaganda is generally regarded as not amounting to direct participation in hostilities.

Loss of protection for media facilities

Media facilities may be targeted for attack if they meet the 'effective contribution to military action' and 'definite military advantage' criteria required by Additional Protocol I. However, as spouting propaganda generally serves only to bolster a party's or military group's political support, an attack that stops such propaganda will general not translate into a 'concrete' or 'definite' military advantage.

Nonetheless, there is strong support for the argument that propaganda which incites people to commit grave breaches of international humanitarian law, or acts of genocide or crimes against humanity, can strip the media facility of its protection as a civilian objective, and transform it into a legitimate military target (Balguy-Gallois, 2004, p. 49). 


\section{Inciting crimes}

The concept of journalists and members of the media being directly involved in crimes such as genocide is a shocking one. However recent jurisprudence from international criminal tribunals indicates that in some cases the media is involved in atrocities. The landmark case dealing with the role of the media in incitement to commit genocide and other crimes was the ICTR trial against Ferdinand Nahimana, Jean-Bosco Barayagwiza and Hassan Ngeze, popularly dubbed 'the Media case'. This case involved the prosecution of three Rwandans alleged to have been the masterminds behind a media campaign to desensitise the Hutu population and incite them to murder the ethnic Tutsi population in Rwanda in 1994. During the Rwandan genocide around 800,000 ethnic Tutsis and moderate Hutus were killed.

Nahimana and Barayagwiza were both founders of the Radio Télévision Libre des Mille Collines ('RTLM'), a radio station that from July 1993 - July 1994, broadcast virulent messages branding Tutsis as the enemy and Hutu opposition members as accomplices. Following the outbreak of the genocide in April 1994, it was alleged that RTLM broadcast lists of Tutsis and moderate Hutus to be killed and gave instructions on where they were hiding.

Hassan Ngeze was the owner, founder and editor of the Kangura newsletter, which was published from 1990-1995 and was widely read across Rwanda. Like the emissions of RTLM, Kangura produced hate-filled messages, characterising Tutsis as 'cockroaches' and enemies who wanted to subvert the democratic system and seize power for themselves

On 3 December 2003, the ICTR Trial Chamber found all three defendants guilty of a litany of international crimes including genocide, direct and public incitement to commit genocide and crimes against humanity for their role in the virulent propaganda churned out by the RTLM and Kangura respectively. Controversially, the Trial Chamber's reasoning seemed to suggest that hate speech or 'an incitement to racial hatred' was sufficient to make out a breach of criminal law, apparently dismissing the requirement that there be an actual incitement to violence as well.

On appeal, the Court of Appeal refrained from criticising the Trial Chamber's apparent confusion of hate speech with breach of international criminal law, but nonetheless 'reiterated' the view that a person cannot be held responsible under international criminal law for 'hate speeches that do not directly incite genocide or other violence among members of an ethnic group'. The 
RTLM's appeal to Hutus to 'do their duty' and publicising the whereabouts of hiding Tutsis was considered sufficient to make out the elements of the crime in the context.

More recently, a former journalist who worked for the RTLM was also sentenced to life in prison for her role in inciting genocide. Valerie Bemeriki was convicted by a grassroots gacaca court in Kigali, which is prosecuting those perpetrators not on trial at the ICTR. ${ }^{3}$

\section{The protection of journalists in non-international armed conflicts}

Although the Geneva Conventions were historically drafted with international conflicts in mind, the vast majority of conflicts since 1945 have been non-international.

International humanitarian law pertaining to non-international armed conflicts is limited to the provisions of Additional Protocol II, and Common Article 3 (so called because it is identical in all four of the Geneva Conventions).

Common Article 3 states that in the case of armed conflict not of an international character each Party to the conflict shall be bound to apply, as a minimum, the following provisions:

(1) Persons taking no active part in the hostilities, including members of armed forces who have laid down their arms and those placed hors de combat by sickness, wounds, detention, or any other cause, shall in all circumstances be treated humanely...

To this end the following acts are and shall remain prohibited at any time and in any place whatsoever with respect to the abovementioned persons: (a) violence to life and person, in particular murder of all kinds, mutilation, cruel treatment and torture; (b) taking of hostages; (c) outrages upon personal dignity, in particular humiliating and degrading treatment; (d) the passing of sentences and the carrying out of executions without previous judgment pronounced by a regularly constituted court, affording all the judicial guarantees which are recognised as indispensable by civilised peoples.

(2) The wounded and sick shall be collected and cared for.

The provisions of Additional Protocol II expand somewhat the bare framework set out in Common Article 3, prohibiting attacks on the civilian population and noting in article 13 that, as with international armed conflicts, civilians only lose such protection if and for such time as they take direct part in hostilities. 


\section{REPORTING WARS}

Although journalists are not specifically referred to in Additional Protocol II, it is now an established principle under customary international law that journalists are classified as civilians in internal armed conflicts (Henckaerts \& Doswald-Beck, 2005).

However, there are some provisions relating to international armed conflicts that are not mirrored in relation to internal armed conflicts, such as prisoner of war status for war correspondents.

\section{The role of the International Committee of the Red Cross}

The role of the ICRC

The ICRC is an impartial, neutral and independent organisation whose exclusively humanitarian mission is to protect the lives and dignity of victims of armed conflict and other situations of violence and to provide them with assistance. The ICRC, together with the National Societies and the International Federation of Red Cross and Red Crescent Societies, form the International Red Cross and Red Crescent Movement (Movement).

Founded in 1863 by Swiss businessman Henry Dunant whose brush with the bloody battle of Solferino spurred him to form an organization to prevent and alleviate suffering in armed conflict, the ICRC was the instigator for the Geneva Conventions.

Pursuant to the Geneva Conventions, States parties are required to permit the ICRC to undertake a range of tasks including to:

- care for the wounded and sick;

- facilitate the institution and recognition of hospital zones and localities;

- $\quad$ visit and give relief to prisoners of war;

- $\quad$ provide parcels of foodstuffs, clothing, medical supplies and other items to prisoners of war;

- forward family messages and other information;

- $\quad$ supply assistance to populations in occupied territory;

- inquire into the whereabouts of missing persons and

- reunite dispersed families.

The movement is guided by seven fundamental principles which must be respected by all components of the movement. They are humanity, impartiality, neutrality, independence, voluntary service, unity and universality.

As a neutral and independent organisation, which does not take sides in 
a conflict, the ICRC has a unique capability to work with warring parties to remind them of their obligations under international humanitarian law and where necessary, persuade them to change their behaviour, through bilateral confidential dialogue. The ICRC believes that engaging in dialogue with armed groups is an effective way of responding to breaches of international humanitarian law. The principle of neutrality also requires the ICRC, and other parts of the Movement, not to engage in matters of controversy.

\section{Practical assistance which ICRC may be able to provide to journalists}

The ICRC runs a 24 hour hotline specially dedicated for journalists requiring assistance while (covering armed conflict and other situations of violence). The service can be accessed by journalists' families, their employers or media to report when a journalist has gone missing, been captured, arrested, detained injured or killed. If the ICRC is operational in the country concerned, contact can also be made directly with the ICRC delegation present.

The ICRC will seek to obtain information from the parties to the conflict and any other sources as to what has become of a journalist. On confirmation of a journalist's detention, capture, arrest or death by the detaining authorities (which may or may not be a government) the ICRC will pass the information onto the journalist's family. It can also pass the information onto the authorities of origin and press association(s) concerned-but only if the family agrees. If a journalist is detained, the ICRC will seek permission for an ICRC delegate to visit him or her accompanied by a doctor if necessary. The ICRC will re-establish contact between the detained journalist and their family, possibly through the exchange of Red Cross messages. In line with its role as a neutral, impartial and independent organisation, the ICRC does not demand the release of a journalist or otherwise advocate for freedom of expression or of information.

The ICRC will also repatriate journalists released from detention, and the mortal remains of journalists who have died and evacuate wounded journalists when no other intermediary is available

In recent years there have been evacuations and repatriation of journalists in relation to the conflicts in Somalia, Colombia and Iraq. In Iraq in 2003, the ICRC was involved in the evacuation of an Australian journalist and the mortal remains of his Australian colleague. The ICRC office in Suleymanieh, Iraq, in 2003, was informed by journalists of an incident involving the two journalists and ICRC staff went to the local hospital to investigate, where they 


\section{REPORTING WARS}

discovered one Australian journalist had been wounded and his colleague killed. The ICRC subsequently organised the necessary documentation with medical and other authorities, and evacuated the wounded Australian journalist and the mortal remains of his colleague by road to the Iranian border, where they were handed over to representatives of the Australian embassy. In addition, the ICRC and National Red Cross and Red Crescent societies regularly run specific training sessions tailored to journalists in order to create a better understanding of international humanitarian law. Understanding international humanitarian law not only makes journalists aware of the protections afforded to them under the law, but also helps ensure the accuracy of their reporting of armed conflicts.

In Australia, the ICRC and Australian Red Cross have been involved in providing regular training sessions for SBS, the multicultural broadcaster, and $\mathrm{ABC}$, the national broadcaster; and one currently providing training to other broadcasters and journalists on an ad hoc basis.

Additionally, in Australia and New Zealand, conferences have been held specifically for the media in order to familiarise journalists with the law and the work of the International Red Cross and Red Crescent Movement. The most recent conference-Reporting Wars: Challenges and Responsibilities was held in Sydney in May 2009 in partnership with the ABC and the University of Technology (a similar conference was held in Wellington, New Zealand). Other such conferences and workshops are organised by the ICRC and partners around the world.

Further, the ICRC also assists journalists around the world through the provision of press materials - such as press releases, bulletins (updating information on specific contexts and providing information on thematic issues such as cluster munitions), provision of photographs and footage. In the field the ICRC regularly briefs journalists on the situation in a given context, and on occasions, security permitting, hosts media visits.

\section{The protection of journalists: Going forward}

Journalists continue to face threats and violence around the world. In this regard, suggestions for a new international treaty creating a special status for journalists and/or a universally recognised emblem which identifies journalists as members of the press have sometimes been made.

Though the idea of granting special status to journalists was discussed 
during the drafting of Additional Protocol I, it was decided that any increase in the number of persons with a special status, 'necessarily accompanied by an increase of protective signs, tends to weaken the protective value of each protected status already accepted' ${ }^{4}$ Though there are still some organisations that continue to call for a special status for journalists, as noted by Saul (p124) most journalistic organisations do not believe that it will make much practical difference to the safety of journalists.

By contrast, the suggestion of a special universally recognised press emblem has in fact drawn much fierce criticism from sections of the profession. The proponents of a protective emblem for journalists argue that such a symbol would differentiate them from combatants and reduce accidental deaths due to confusion. Its critics argue that drawing attention to the fact that they are media personnel could mean that journalists are easily targeted by those who want to suppress the media.

The Broadcast News Security Group, comprising the BBC, ITN, Sky, Reuters, APTN, CBS, ABC, CNN and NBC, argues strongly against use of a universal press emblem, claiming that it would be more dangerous for journalists to clearly mark themselves due to the fact they are being targeted as never before. Likewise, the Committee to Protect Journalists remarks that it would 'worsen security by identifying journalists to all those who might target them for violence', also adding that an emblem would be:

undesirable because it would require a licensing entity to determine who is and who is not a journalist. It would open the way to restrictions on the press by encouraging governments to establish regulatory controls on journalists within their own nations. (INSI, 2007)

It appears that agreement on a universal emblem is unlikely. In the absence of such an emblem, journalists may decide to use the letters TV or PRESS, on their clothing or the roof of their vehicle, etc, to identify themselves as members of the media, but this is a decision that should be made by the individuals and their employers.

With journalists not only protected as civilians but specifically articulated as requiring protection in international humanitarian law, the issue of better protection appears to lie not more in law but in the increased implementation and respect of agreed upon the legal principles. Saul, for example, argues that 'inadequate implementation and enforcement of the existing international law 
applicable to journalists in armed conflict and other dangerous situations may well be of greater significance than any normative deficiencies in the law itself.'

This argument has not gone unnoticed by the international community. Dismayed by the continuing violence against journalists, the UN Security Council in 2006 adopted Resolution 1738, unanimously condemning attacks against journalists in conflict situations and calling on all parties to put an end to such practices. The UN Security Council reiterated the fact that journalists engaged in dangerous professional missions in areas of armed conflict are considered civilians and that war correspondents are to be granted status as prisoners of war $^{5}$. The Council further emphasised 'the responsibility of States [to protect journalists]', as well as States' obligation to end impunity and to prosecute those responsible for violations of the rights of journalists. However, there is little evidence to show that even this strong statement has made much difference to the on-the-ground situation that journalists reporting on armed conflicts face.

Consequently, journalists must take steps to secure their safety while on assignment. This means having appropriate training and safety equipment, and a good understanding of the country to which they are travelling.

As discussed, good knowledge of international humanitarian law is crucial and should be part of journalists training and preparation for reporting armed conflicts - first because it assists in accurately reporting war crimes and other atrocities. But secondly because it will allow journalists to raise the alarm when they themselves are victims of a breach of international humanitarian law. The ICRC and National Red Cross Societies continue to work hard to disseminate the principles of international humanitarian law to journalists.

Most importantly, however, it is the education of combatants that may cause a real shift in the enforcement of international humanitarian law. In continuing to remind those engaged in the heat of battle that the principles of international humanitarian law must be respected, as well as providing practical support to journalists when possible, the International Red Cross and Red Crescent Movement continues to make an extremely important contribution to the safety of journalists. 


\section{Notes}

1. Geneva Convention I, art. 49; Geneva Convention II, art. 50; Geneva Convention III, Art. 129; Geneva Convention IV, Art. 146.

2. Commentary on the Draft Additional Protocol to the Geneva Conventions of 12 August 1949, cited in Official Records of the Diplomatic Conference on the Reaffirmation and Development of International Humanitarian Law Applicable in Armed Conflits, Geneva (1974-1977), Vol XIV, p14, para 8, ICRC, CDDH/III/SR2. 3. ABC, News 'Journalist, singer jailed for life over Rwanda genocide', 15 December 2009,www.abc.net.au/news/stories/2009/12/15/2771636.htm?section=justin at 4 January 2010.

4. Sandoz, Swinarski and Zimmerman (eds), Commentary on the Additional Protocols of 8 June 1977 to the Geneva Conventions of 12 August 1949, ICRC/ Martinus Nijhoff Publishers, Geneva, 1987, para 3265.

5. UN Security Council Resolution 1736, www.un.org/News/Press/docs/2006/ sc8929.doc.htm at 2 January 2010.

\section{References}

Balguy-Gallois, A. (2004). The protection of journalists and news media personnel in armed conflict.

Henckaerts. J and Doswald-Beck. L, Customary International Humanitarian Law, Volume I. Rules, Cambridge University Press, 2005, pp. 115-118.86 International Review of the Red Cross, 86(853), 37-49.

INSI (International News Safety Institute) (2009). World death toll for journalists shoots up in 2009 despite safety calls. Retrieved on 4 January 2010, from www. newssafety.org/index.php?option $=$ com_content\&view=article \&id $=17300 \&$ catid $=314$ \&Itemid $=100077$

ICRC (International Committee for the Red Cross). (2009). Interpretive guidance on the notion of direct participation in hostilities under international humanitarian law. Retrieved on 4 January 2010, from www.icrc.org/Web/eng/siteeng0.nsf/htmlall/ direct-participation-report_res/\$File/direct-participation-guidance-2009-icrc.pdf

ICRC (International Committee for the Red Cross). (2008). States party to the Geneva Conventions and their Additional Protocols. Retrieved on 20 January 2010, from www.icrc.org/Web/eng/siteeng0.nsf/htmlall/annual-report-2008-map-convenA3/\$File/icre_ar_08_map_conven_A3.pdf

ICRC (International Committee for the Red Cross). (2007). Red Crystal: The 'emblem protocol' comes into effect. Retrieved on 20 January,2010, from www.icrc.org/ web/eng/siteeng0.nsf/html/emblem-keyfacts-140107

International News Safety Institute, 'Killing the Messenger: The deadly cost of news' (2007) www.newssafety.org/images/pdf/KillingtheMessenger.pdf at 4 January 2010. 


\section{REPORTING WARS}

Saul, B. (2008) The international protection of journalists in armed conflict and other violent situations. Australian Journal of Human Rights, 14(1), 99.

SS Lotus (France v. Turkey) (1927). PCIJ Rep. Series A, No. 10, p. 19.

Sophia Kagan is a lawyer with Minter Ellison Lawyers, Melbourne, Australia, and Dr Helen Durham is the strategic adviser, international law, for the Australian Red Cross. Any views expressed in this article are purely those of the authors and do not represent any institutional views. The authors would like to thank Pip Ross for her assistance.

hdurham@redcross.org.au

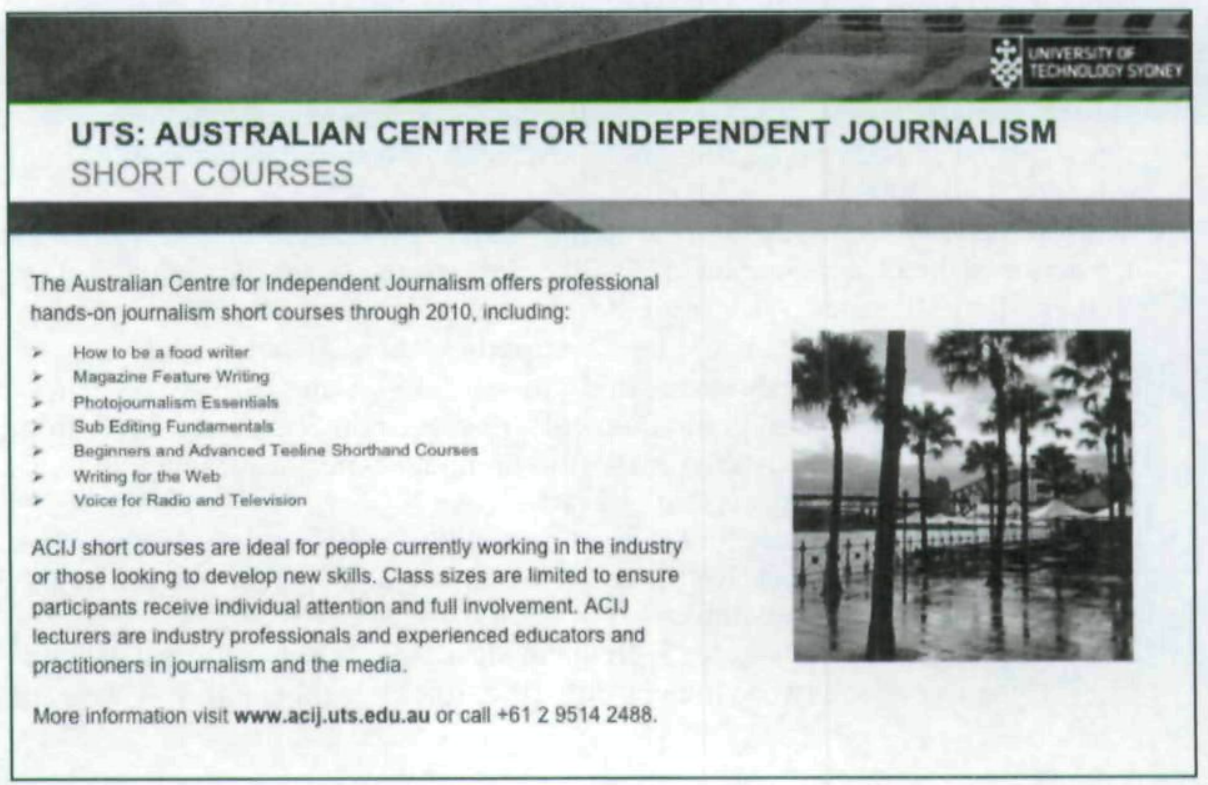


Copyright of Pacific Journalism Review is the property of Auckland University of Technology and its content may not be copied or emailed to multiple sites or posted to a listserv without the copyright holder's express written permission. However, users may print, download, or email articles for individual use.

http://www.aut.ac.nz/depts/commstud/journ/pjrsubs.shtml 